\title{
Process-Control in Job-Shop-Scheduling with the Aid of PERT
}

\author{
正 木下 和久 （大分大） \\ Kazuhisa KINOSHITA,Oita University,Dannoharu 700,Oita-city,Oita
}

\begin{abstract}
Owing to a variety of markets needs, various requirements for products have been requested. In the case of job-shop-scheduling,the most difficult problems are the dispatching of the order of manufacturing and ensuring safety and reliability. Therefore, to accomplish the low cost of systematization,detailed investigations are needed. In order to take the process automatically, the authors have suggested the model where the Programm Evaluation Review and Technique (PERT) and the Critical Path Method (CPM) were used heuristically and visually at real time. In this situation, the most suitable solution means the state in which the process-control satisfy the considerable minimum cost. Key Words: Process Control, Job Shop Scheduling, PERT, CPM
\end{abstract}

\section{1. 緒言}

特定の製造業界では、受注する製品の種類は仕様、ロット 数、納期、発注時期、発注間隔がランダムであり、相手先も 国内、国外と多岐に渡っている。それゆえ、生産形態忙多品 種少量、受注型であり、生産コストを考慮して製造の順序を きめるのは、非常に困難を極めている状態である。現状は長 年の経験と堪により、种期を中心として順序を決めている。 この結果、行程間に無理、無䭾、ムラのロスが生じ、従業員 の配置とも関係して生産コストを押し上げている。また、㥵 手先に対して、一応の納期は示しているものの、製造者自身 が完成期日・納期を把握できる状況にない場合もある。

一方、工程管理に対しては、オペレーションズ・リサーチ （OR）の分野で、数理計画法による解法また近似解を求め るために分岐限界法などが研究・開発されているが、ジョブ の組み合わせが多い場合には計算が困難になる。解决するに は、コンピュータシステムが大拱かりになるので、一般的に は中小企業では対応できない。次に、日程管理に対しては 従来からのガントチャート、山積み・山崩しなどがあるが、 ジョブとラインの数が多くなると各工程間の相関関係の識別 と判断は難しくなる。

著者らは先に生産設計に関する研究を報告した(1)-(3)。 本研究においては、特定の製造工場における工程指示問題を 克服するための一手法を提示する。

\section{2. 解決手法の新規性}

最初に、以下の問題点の抽出を行う。

【 i 】 多品種・少量生産形態

【ii】ジョブ・ショップ・スケジューリング問題

【iii】ディスパッチング（差し立て）の難しさ：順列組合せ 次に、解決法の一陚案としては、下記の事項が有用である。

【iv】ヒューリスティック法

【v】評価関数（重みづけ）:エキスパートのデータ

【vi】計算処理を迅速化し、順列組合せ問題の負担軽減

【vii 計算結果を P E R T （Programm Evaluation Review and Technique とC PM (Critical Path Method)のネッ トワークに連携させて図示

【viī工程管理を担当者が目で確認でき判断が容易

【ix】リアルタイムでフィードバック：何度でも修正可能 【x】判断する際の誤差を僅少化

このように、斬新な連携処理により、かなり効果的な工 程指示を行うことが可能である。

3.モデル化の具体的な目標

3-1 生産コスト削減

工程指示管理の自動化を行い、熟練管理者の経費削減、製 造指図書の誤記、工数のまちがい、パーツの迷子捜しの時間 的口ス、工作の待ち時間のロス、従業員の配置・割り振りの 調整・管理、従業員の就業時間と残業時間の調整・管理、機 械の稼働率を向上、原価計算と日報、週報、月報を作成し、 所期のトータル生産コスト削減を目標とする。

3 - 2 市場性について

製造メーカーに対する市場性もあり、かなりの普及率が見 込まれ、新しいビジネスチャンスが創出される。その他、ソ フトプログラムの販売会社の創出と工程管理・スケジュール 管理ソフトを用いて会社の生産コストを低減したいと考えて いる中小・零細企業に新規需要が認められよう。

\section{4. モデル化の具体的内容}

本研究は多品種の工場の受注形態（順列組合せの問題）を 効率よく指図して、リアルタイムでパソコン画面上に表示し、 直接視覚による確認をし、納期の確約と生産コストの削減を 目的とする。概略を図 1 に示す。手順は以下の様である。

(1) 所定期間の注文品をコンピュータにデータ入力

（2）評洒関数を選択する。ーーーたとえば、納期

(3)計算（納期に重みを置いた処理）

(4) パソコン画面上に P E R T のネットワーク、C P M、 バーチャートの図が表示される。 


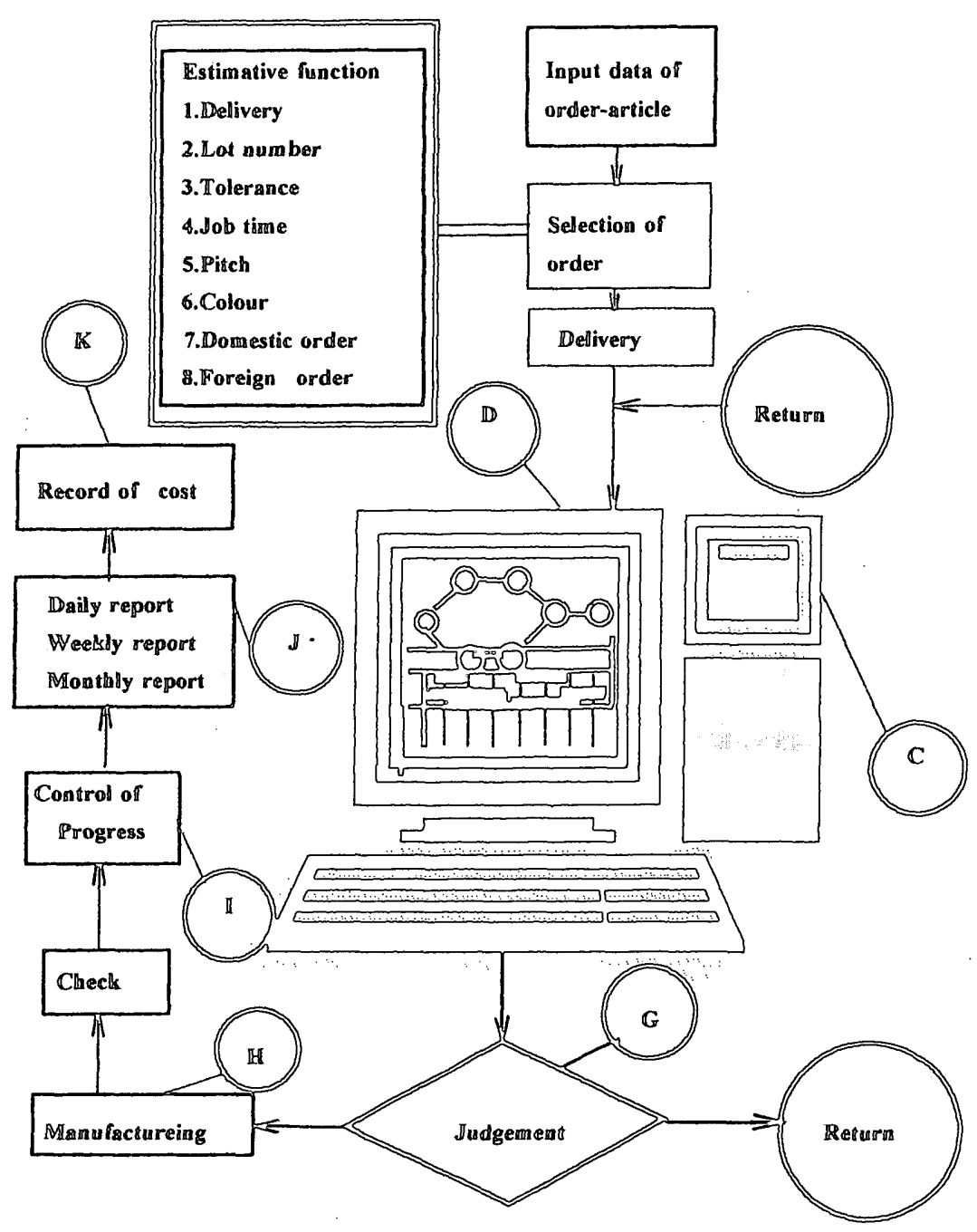

Fig. 1 Flow chart of a model

（5）各工程の作業日数、余裕日数、納期、生産コストが 確認できる。

（6）キーボードを操作することにより、次の製品のネッ トワーク図が示され、同様にしてすべての製品の日程 と納期と生産コストが表示される。

（7）各工程の日数と人員配置をチェックする。

（8）修正事項があればパソコンに入力

(9) 再度画面に表示

（１０）評価関数（たとえば、寸法公差など）を変えて、 上記（2）加（9）の手順を繰り返す。

（1１）経営者と管理者が判断し、順序づけを決定

（1 $\left.\begin{array}{ll}1 & 2\end{array}\right)$ 製造開始

（13）進捗状況の管理とフィードバック

（1 4） 日報、週報、月報の作成

（1 5）最終の生産コストの記録

\section{5. 実際の用途}

(1)製造工場における工程指示管理の自動化

(2)日程管理をアローダイアグラムとしてパソコン画面上で 視覚化

(3)スケジュールの進捗状況の把握

(4)従䓺員の配置・割り振りの調整・管理

(5)就業時間・残業時間の調整・把握

(6)機械の稼働率の把握
(7)原価計算と生産コストの計算

\section{6. 結言}

コンセプトの効果として、製造業界の生産ラインにおいて、 ロスタイムを淢少させる。従業員を効果的に配置できるので コストが削減される。納期が確約できるので、チャンスを逸 しないですむ。国内のみならず、外国の競合メーカーに対し て、優位に立てる。ソフトプログラム販売会社の創出が期待 できる。受注形態の中小企業において、業種が異なっても管 理手法は転用可能であるので、潜在的な需要が見込まれる。

本研究は現在もさらに進行中であり、課題を一つずつ解决 し、機会を見て報告したいと考えている。

参考文献

(1) $\mathbb{K a z u h i s a ~ K i n o s h i t a ~ ほ か 、 ~}$

Proceedlings of the First Intermational Conferemce on Quality and Reliability,

11-12 April 1995 Hong Kong, Volume 2,pp.181-184

（2）不下和久 ほか

大分大学工学部研究報告、第 32 号

平成 7 年 9 月 29 日, p p. $33-37$

(3) Kazuhisa Kimoshita ほか、

Proceedings of IMCC,95, Vol.2, 1995-10,pp.535-539 